Journal of Marketing Management, Volume 27, Numbers 7-8, July 2011, Pages 691-717

\title{
Measuring Communication Channel Experiences and their Influence on Voting in the 2010 British General Election
}

\author{
Paul Baines \\ Emma Macdonald \\ Hugh Wilson \\ Cranfield School of Management, UK \\ Fiona Blades \\ MESH Planning
}

Address for Correspondence:

Dr Paul Baines

Cranfield School of Management

Cranfield MK43 0AL

UK

Tel.: + (0)1234 751122

Email: paul.baines@cranfield.ac.uk

Accepted for publication in Journal of Marketing Management, Vol.27, forthcoming 


\title{
Measuring Communication Channel Experiences and their Influence on Voting in the 2010 British General Election
}

\begin{abstract}
This article describes how a unique research approach was used to evaluate how different communication channel experiences influenced floating voters during the campaign period of the 2010 British general election. Most previous research focuses on voting behaviour as a single crosssectional phenomenon, and on self-assessments of the relative importance of marketing communications - during, or more typically after, the campaign. This study outlines the influence of different marketing communications (including word-of-mouth and PR through mediated communications) over time using a longitudinal panel of floating voters and a real-time tracking approach. Results indicate the relative importance of the debates, used in 2010 for the first time in the UK, and more surprisingly the relative importance of party election broadcasts and posters.
\end{abstract}

Keywords: political marketing, channel effectiveness, marketing influence, real-time experience tracking.

\section{Author Biographies}

Paul Baines is Reader in Marketing at Cranfield School of Management and Course Director, MSc Strategic Marketing. Paul is Managing Editor, Europe, of the Journal of Political Marketing. He is author/co-author of more than hundred published articles, book chapters and books on marketing, political marketing, propaganda and public opinion issues, the most recent of which was the bestselling, Marketing (with Chris Fill and Kelly Page), published by Oxford University Press (2008, 2011) and the three-volume set Political Marketing, published by Sage Publications (2011). He is also the director of Baines Associates Limited, a strategic marketing/research consultancy. 
Emma K. Macdonald is Senior Research Fellow in Marketing, Deputy Director of the MSc in Strategic Marketing and principal researcher of the Cranfield Customer Management Forum. Her research interests include customer experience, engagement and empowerment. In particular she is investigating the role of customers in value co-creation and assessment, and in developing new techniques for assessing customer experience in real time. Emma joined Cranfield from London Business School. Before academe, Emma worked in telecommunications marketing management and as a commercial researcher conducting brand, ad, and new product research for leading consumer brands.

Hugh Wilson is Professor of Strategic Marketing and Director of the Cranfield Customer Management Forum at Cranfield School of Management. He is listed in the Chartered Institute of Marketing's global 'Guru Gallery' of 'the 50 leading marketing thinkers alive today' (www.shapetheagenda.com). He has extensive industrial experience with IBM, Logica CMG and others. His research has been published in Journal of the Academy of Marketing Science, Journal of Business Research, Industrial Marketing Management, British Journal of Management, European Journal of Marketing, Journal of Marketing Management amongst other journals, and he also writes extensively for practitioners. He was honoured by the DTI as one of the 'Internet Decade' list of the hundred individuals who have had most influence over the development of e-commerce, according to an NOP poll.

Fiona Blades is Chief Experience Officer at MESH Planning. Following a career as a Marketing Manager for Spillers Foods and as an Advertising Planning Director, Fiona set up MESH Planning in 2006 to create a new real-time research approach to evaluate every touchpoint from TV advertising to in-store to word-of-mouth. Listed in the entrepreneurs' section of Research magazine's 50 Faces to Watch in 2007, Fiona frequently speaks at industry events. She is a member 
of Cranfield's MSc Strategic Marketing Practice Advisory Board, designed to strengthen ties between Cranfield and industry. She sits on the Hackney and City Carers Partnership Board. 


\section{Measuring Communication Channel Experiences and their Influence on Voting in the 2010 British General Election}

\section{Introduction}

The 2010 British general election was unusual in that it returned a Liberal-Conservative coalition government, putting the Liberals back in power for the first time since David Lloyd George was Prime Minister in the 1920s. A tired Labour government, ousted after 13 years, replaced a tired Conservative government which itself had ruled for 17 years. Gordon Brown replaced Tony Blair as Labour leader in 2008, just as the United Kingdom plunged into recession, but Brown and his party did not ignite the voters' interests and passions. But then neither did David Cameron's Conservative Party, and despite an average Conservative lead in voting intentions of $15-16 \%$ over Labour in May/June 2009 (Worcester et al, 2011: 138), the Conservatives failed to secure sufficient vote share to win the election, ending only $7 \%$ and 48 seats ahead of Labour (Mortimore, 2010). In many ways, it was the campaign the Conservatives lost. And seemingly, the Liberals won it given that they achieved a share of power. But parties always claim that they have won an election, by redrawing the boundaries of their success ex post. If who won the election is a question with multiple subjective answers, in this article we seek to answer a question which is perhaps more useful both for political marketers and for scholars of integrated marketing communications more broadly: how might we determine how the election (marketing) campaign influenced voting intentions, and what role was played by different communication channels?

\section{Measuring the influence of communication channels in politics}

There are few studies in the politics context evaluating the effectiveness of different marketing techniques (or touchpoint experiences as we call them). Most national opinion pollsters (e.g. YouGov, ICM Research and NOP) have tended to track changes in voting intention, rather than evaluating the effectiveness of the campaign per se. Ipsos MORI in contrast has for many years asked a question post-election about what most influenced the way a respondent voted (see Table 
1). This approach has pointed to the relative importance of the TV debate between the party leaders in both 2001 and 2005 (although commonly referred to as leaders' debates in the press (see BBC, 2005a), there were actually differences in format between the 'debate' programmes for these two elections and the format changed yet again in 2010) ${ }^{1}$. Newspapers were the second most influential item and party election broadcasts (PEBs) came a close third place in influence terms, on this selfreported measure. However, from a scholarly perspective, this question is likely to be flawed, as consumers are famously bad at assessing what has influenced their decision-making, often erroneously believing that communications exert a stronger influence on others than they do on themselves (see Perloff, 1999, for a detailed review of the 'Third Person Effect'). Voters frequently also misremember their past vote (Himmelweit, Jaegar \& Stockdale, 1978).

Scholars would therefore prefer to focus on statistically inferring influence from examining the association between relative exposure (typically measuring recall and recognition) and subsequent attitudes and behaviours. Yet, such research frequently contains insufficient granularity to establish how, if at all, message receipt results in message persuasiveness. This is also a problem in practitioner research which has not delved into exactly how these items persuade. In Table 1, was it newspaper editorial that persuaded (we presume so) or the parties' newspaper advertising? The use of recall (as data tend to be collected in a cross-sectional survey) also presents difficulties with data validity. In 2005, for example, if we extrapolate those that stated that they were persuaded by the leaders' debate (21\%), hosted by David Dimbleby, to the voter population (see Hames \& Passmore, 2005: 296), we obtain about $9 \mathrm{~m}$ people. This is $4.9 \mathrm{~m}$ more than were actually recorded as having watched it (BBC, 2005a)! Nevertheless, the answer might indicate something else: that the extra

\footnotetext{
${ }^{1}$ Election debates in 2001, 2005 and 2010 differed in format in that in 2001, the three main party leaders appeared separately on three separate editions of Question Time, facing questions drawn from a studio audience (BBC, 2001). In 2005, the three main party leaders appeared together in the same Question Time programme but sequentially answering questions for 30 minutes each from a live TV audience (BBC, 2005b). Finally, in 2010, three separately themed debates were held by BBC, ITV and Sky News where all three parties' leaders appeared together to take questions from a live studio audience (Sparrow, 2010). For an interesting discussion of how the debates differed in 2001 compared to those operating in Presidential elections in America, and an accurate forecast of the likely evolution of the debate format in 2005 and 2010, see Hansard Society (2001).
} 
people were persuaded not by the leaders' debate per se but by the media discussion of the debate afterwards on broadcast television, in newspaper columns and on the internet. With traditional polling methods, it is difficult to determine the answer to this conundrum. While it is laudable that Ipsos MORI have previously collected this influence data, what is also clear from these responses is that around $50 \%$ of people claim not to be influenced by any of the items listed. Yet, is that really the case? Or are people simply understating the effect of these media? If they are not understating the effect, are they persuaded by something else not listed? If yes, is it marketing-related or related to something other than the marketing component of the campaign? These questions remain unanswered with the standard polling technique because it does not identify effects per se; rather, it identifies self-reported perceptions.

Table 1: Self-reported campaign influences, 2001 and 2005

Q Which of these items, if any, have influenced the way you intended to vote?

\begin{tabular}{|c|c|c|c|c|c|c|c|c|}
\hline & \multicolumn{4}{|c|}{ 24-30 May 2001} & \multicolumn{4}{|c|}{ 5-10 May 2005} \\
\hline & $\begin{array}{c}\text { All } \\
\%\end{array}$ & $\begin{array}{c}\text { Con } \\
\%\end{array}$ & $\begin{array}{c}\text { Lab } \\
\%\end{array}$ & $\begin{array}{c}\text { LD } \\
\%\end{array}$ & $\begin{array}{c}\text { All } \\
\%\end{array}$ & $\begin{array}{c}\text { Con } \\
\%\end{array}$ & $\begin{array}{c}\text { Lab } \\
\%\end{array}$ & $\begin{array}{c}\text { LD } \\
\%\end{array}$ \\
\hline None of these & 50 & 54 & 44 & 46 & 52 & 54 & 51 & 35 \\
\hline The TV debate between the party leaders\# & 21 & 18 & 24 & 24 & 18 & 17 & 20 & 26 \\
\hline Newspapers & 15 & 20 & 15 & 18 & 14 & 15 & 14 & 17 \\
\hline Party election broadcasts & 14 & 16 & 18 & 12 & 12 & 11 & 13 & 17 \\
\hline The views of your local candidates & 13 & 12 & 16 & 16 & 12 & 11 & 11 & 22 \\
\hline Political leaflets through your letterbox & 6 & 7 & 6 & 8 & 8 & 7 & 6 & 14 \\
\hline Other & 4 & 3 & 4 & 5 & 7 & 6 & 7 & 8 \\
\hline Opinion polls & 4 & 2 & 5 & 3 & 3 & 2 & 4 & 5 \\
\hline Posters on billboards & 2 & 3 & 2 & 2 & 3 & 3 & 4 & 4 \\
\hline Internet & 1 & 1 & 1 & 2 & 2 & 3 & 2 & 4 \\
\hline Don't know & 2 & 0 & 2 & 1 & 1 & 1 & $*$ & 1 \\
\hline Telephone calls from political parties & 1 & 0 & 1 & 1 & $*$ & $*$ & $*$ & $*$ \\
\hline Video received from political party & 0 & 0 & 0 & 0 & $*$ & $*$ & $*$ & $*$ \\
\hline
\end{tabular}

Note: * less than 1\%.\# the leaders' TV debate format changed between 2001 and 2005 and technically neither programme was a debate between the leaders but rather a debate between each leader and the studio audience, moderated by David Dimbleby in a Question Time special election programme.

Source: Worcester, Mortimore and Baines (2005:207); Base: 2,058 GB residents aged 18+, 5-10 May 2005

There have been some academic assessments of the impact of marketing communications in political campaigns, albeit frequently based on an individual communication medium.

Scholars have deconstructed the use and misuse of party election broadcasts (PEBs) using content analysis (Scullion \& Dermody, 2005; Scammell \& Langer, 2006) and evaluated the positivity 
versus negativity of political advertising (Kaid \& Johnston, 1991). One study (Kaid, 2002) compared the use of political advertising through traditional channels with political advertising on the internet, concluding that in the 2000 US presidential election campaign 'undecided voters exposed to internet political advertising changed their vote preference to $\mathrm{Al}$ Gore, whereas undecideds who viewed the same spots on television changed their preferences in favour of George W. Bush'. A more holistic study of political advertising believability and information source value in Australia (O'Cass, 2002) concluded that non-paid media (television and newspaper reportage) were valued more as sources of information than political advertising and, at that time, the internet. Interestingly, the more information voters seek out, the more confident they are in their political choices (O'Cass \& Pecotich, 2005), indicating the importance of developing effective and efficient channels for informing voters.

There has been a long tradition of evaluating consumer response to negative advertising with equivocal results, with some arguing that its use reduces voter trust long-term (Dermody \& Scullion, 2003; Dermody \& Hanmer-Lloyd, 2005), others arguing that negative information is weighted more strongly than positive information because it is frequently more diagnostic or relevant (Skowronski \& Carlston, 1989; Klein \& Ahluwalia, 2005), and still others arguing that negative advertising can induce negative impressions toward both the target and the sponsor (Merritt, 1984).

There have previously been a number of attempts to understand the nature of marketing effects in political campaigns. For example, Norris et al (1999: 187-197) used a mixed methods approach combining a cross-section survey, a campaign panel study, a content analysis of television and press news and an experimental study of television news (with each survey using a differently constituted sample) during the 1997 British general election to evaluate media effects on voting choice. Romer, Kenski, Waldman, Adasiewicz and Jamieson (2004) set out specifically to capture campaign 
dynamics in the National Annenberg Election Survey using a rolling cross-sectional analytic research design. Such a design helps to uncover potential causal relations in the data. De Vreese and Semetko (2004:177) also identified campaign effects in their study analysing the Danish 2000 Euro referendum in which they conclude that referendums can lead citizens to evaluate the campaign positively or negatively, induce political cynicism, affect citizen's evaluations of political leaders, serve to crystallise opinion on the topic of the referendum and influence some voters on how to vote. Interestingly, when Professor Phil Harris (now at the University of Chester) testified as an expert witness in a judicial review of the 1996 Irish Divorce Referendum as to the effectiveness of marketing and the relative advantage which the 'Yes' campaign (anti-abortion) was afforded through government expenditure, three high court judges disagreed with his evidence, arguing on the basis that in their view 'marketing and market-research based evidence did not indicate that the government's marketing campaign materially affected the result; they judged that knowledge from marketing could not be transferred to the political domain' (Harris, Lock \& O'Shaughnessy, 1996), effectively deeming that it is not possible that people could be affected by something so trivial as advertising given the gravity of the topic of divorce as a political issue in Ireland.

\section{Measuring the influence of communication channels in commerce}

In the commercial context, the evaluation of communication channel effectiveness is as frequently poor or non-existent as it is in the political context: 'how to measure IMC [integrated marketing communication] programs seems to be an issue that most executives are not able to clearly answer' (Schultz \& Kitchen, 1997). Nonetheless, a body of best practice does exist in practitioner and scholarly research. Three broad approaches dominate: 1) experimental; 2) individual-level multivariate; and 3) aggregated multivariate, or econometric modelling.

There is a long history of academics using experimental approaches in a laboratory context to explore principles of consumer response to communications (see Simon \& Arndt, 1980). While 
most studies look within a single communications channel such as television (Park \& Young, 1986), print advertisements (Mehta \& Purvis, 2003), posters/billboards (Taylor, Franke \& Bang, 2006), or even text message advertising (Rettie, Grandcolas \& Deakins, 2005), some examine the relative effects of multiple channels (Nicolson, Clarke \& Blakemore, 2002; Courtheoux, 2003). These laboratory experiments are clearly limited in ecological validity, or the extent to which findings can reliably be translated to real-life settings, by the laboratory setting and, frequently, by unrepresentative samples of students or other convenience populations. Field experiments improve ecological validity by manipulating variables in the field context (Ryals \& Wilson, 2005). This is easiest to do with targeted communications such as direct mail, where the impact on both attitudes (Milne \& Gordon, 1994) and behaviour (Verhoef, 2003) is hence easy to assess. Mass communication methods such as television advertising often rely on quasi-experiments or single cross-sectional studies (Moschis \& Moore, 1982) which approach the logic of randomisation as closely as possible, for example by comparing regions.

The difficulties of manipulating such variables as communications exposure in the field, however, make field experiments relatively rare. Post-hoc multivariate approaches are, therefore, often used. These examine individual communications exposure to multiple communications and tease out their relative effects by such means as regression and structural equation modelling (see Merrilees \& Fenech, 2007, for a discussion of both approaches). While having the benefit of comparing relative effects of communications channels, the drawbacks of such individual-level multivariate analysis primarily relate to the difficulty in obtaining good data. As the primary data source is generally a cross-sectional survey, such as a brand's monthly brand tracker, communications exposure is selfassessed perhaps several weeks after it occurs, presenting difficulties, not least because consumers may not always attend carefully to brand information (Cowley, 2002). Furthermore, any selfassessment of response to the individual communication will be subject to a re-evaluation over 
time; emotions, in particular, are often fleeting (Keltner, Kring \& Bonnano, 1999) and will frequently be reconstructed in retrospect (Cowley, 2008).

The cross-sectional survey also presents validity difficulties in the dependent variable. While shifts in attitude can be effectively tracked in this manner, subsequent impacts on behaviour rely either on recontacting respondents (Verhoef, 2003) or on combining survey data with objective sources such as CRM systems (Lichtenstein, Bednall \& Adam, 2008). Dominantly, therefore, individual-level multivariate analysis is used to examine shifts in brand attitudinal metrics, and companies rarely use customer-level longitudinal data at industry level to develop marketing productivity (Rust, Ambler, Carpenter, Kumar \& Srivastava, 2004).

To check on the financial impact of communications, therefore, aggregate data across all respondents is used to ascertain return on marketing investment econometric models (COI/GCN, 2009:40) or marketing mix models (Pfeiffer \& Zinnbauer, 2010). These employ as the unit of analysis not individuals but time periods or horizontal units such as regions or stores. Dependent variables based typically on spend across paid media types are examined for their association with a dependent variable such as market share, sales or market size. This approach again has evident strengths, but also some weaknesses as follows: data for dependent variables is often restricted to paid media, although proxies for public relations such as the number of press releases on a topic have been used; to gain sufficient units of analysis requires monthly or weekly data over a substantial period, or equivalently a large number of spatial units such as regions; the method assumes that media spend approximates to media consumption; and individual response to communications cannot be fed into the analysis as a measure of communications quality as opposed to quantity (Naik \& Peters, 2009). 
If, then, evaluation of communications effectiveness for paid media is patchy, evaluation of wider aspects of the customer's experience of the brand is even more so. The argument that customers experience the brand holistically across communication encounters, service encounters and usage encounters (Verhoef et al., 2009) has begun to receive empirical support. Lemke, Clarke and Wilson (2011) find that customer experience includes such indirect touchpoints as the relationship with other customers, contact with the firm's own suppliers, and the social impact of brand support, in addition to direct communications and service touchpoints with the brand owner. Word-of-mouth is a case in point. While much research using individual-level multivariate analysis examines drivers of word-of-mouth as a dependent variable (de Mattos \& Rossi, 2008), the understanding of word-of-mouth as an independent variable is, by comparison, immature (East, Hammond \& Lomax, 2008), and rarely studied analytically by practitioners.

In summary, while commercial assessment of communications channel effectiveness offers a number of useful approaches, these are collectively flawed in practice in three respects. First, holistic assessment of the customer experience across both paid-for and unpaid-for communications channels, while often called for, is rarely undertaken. Second, and related, the validity of exposure measures is poor due to retrospective self-assessment or the use of media spend as a proxy. Third, while some approaches such as econometrics measure behaviour as a dependent variable, in the many cases in which econometrics are impractical the dependent variable is often an attitudinal antecedent to behaviour rather than the behaviour itself. While no method is perfect, we reduce some of these difficulties in the method adopted for this study.

\section{Method}

Our study of 'floating voters' was conducted using a combined online and mobile phone survey collection method. Data were collected continuously throughout the four-week campaign period of the election and beyond the day of voting. Data collected included demographics, voting intentions, 
actual voting, and encounters with a large variety of touchpoints experienced during the campaign including communications generated and/or controlled by the relevant parties, as well as those generated by the media and other sources, such as word-of-mouth through peers. (We follow Lemke, Clarke \& Wilson, 2011, in using the term touchpoint to cover all encounters with the brand - in this case, the three main UK political parties - as this term is broader than the notion of media exposure.) Data were collected in two forms. Firstly, an online survey was used for collecting demographics, voting intentions, and perceptual measures at the start of the campaign; these measures were repeated at the end of the study with an additional request for actual voting behaviour. Secondly, mobile phone text messaging was used to capture contemporaneously, or in 'real time', the election touchpoints encountered by an individual during the four week period of the study. The granularity of touchpoint information provided by the mobile phone methodology, combined with pre-and-post comparisons between intentions and behaviour, enabled an analysis of the impact of various touchpoints on voting behaviour.

\section{Sampling}

A sample of floating voters (defined as respondents who were not 'absolutely certain' about which party they would vote for) was recruited via an online panel (by market research company Research Now). The panel used quota sampling to recruit a sample of 1,100 respondents, representative of the UK population in terms of region, social status, age group and gender. Respondents were also screened on the following criteria: 1) access to a mobile phone, 2) ability to send text messages from their phone; and 3) willingness to use their mobile phone to participate in the research. Due to the four-week commitment required from respondents involved in the study, there was a significant drop out rate $(56 \%)$, although drop-outs were replaced with respondents of a similar profile. However, for the purposes of this study, in other words to test an innovative new method of panel data collection and to identify the effects of communication experiences on voters, the final sample selected used only those floating voters who participated throughout the whole period of the study. 
Thus, a true panel was used (Parasuraman, 1991:144). Therefore, the final usable sample of respondents was $n=480$ which included those who completed both the time-zero ( $t 0)$ and time-one (t1) surveys, plus four weeks of 'real-time' tracking. The sample of 480 showed a slight bias to the higher socio-economic groups but was fairly balanced with respect to age groups and gender (see Appendix A).

\section{Figure 1: Design of the study}
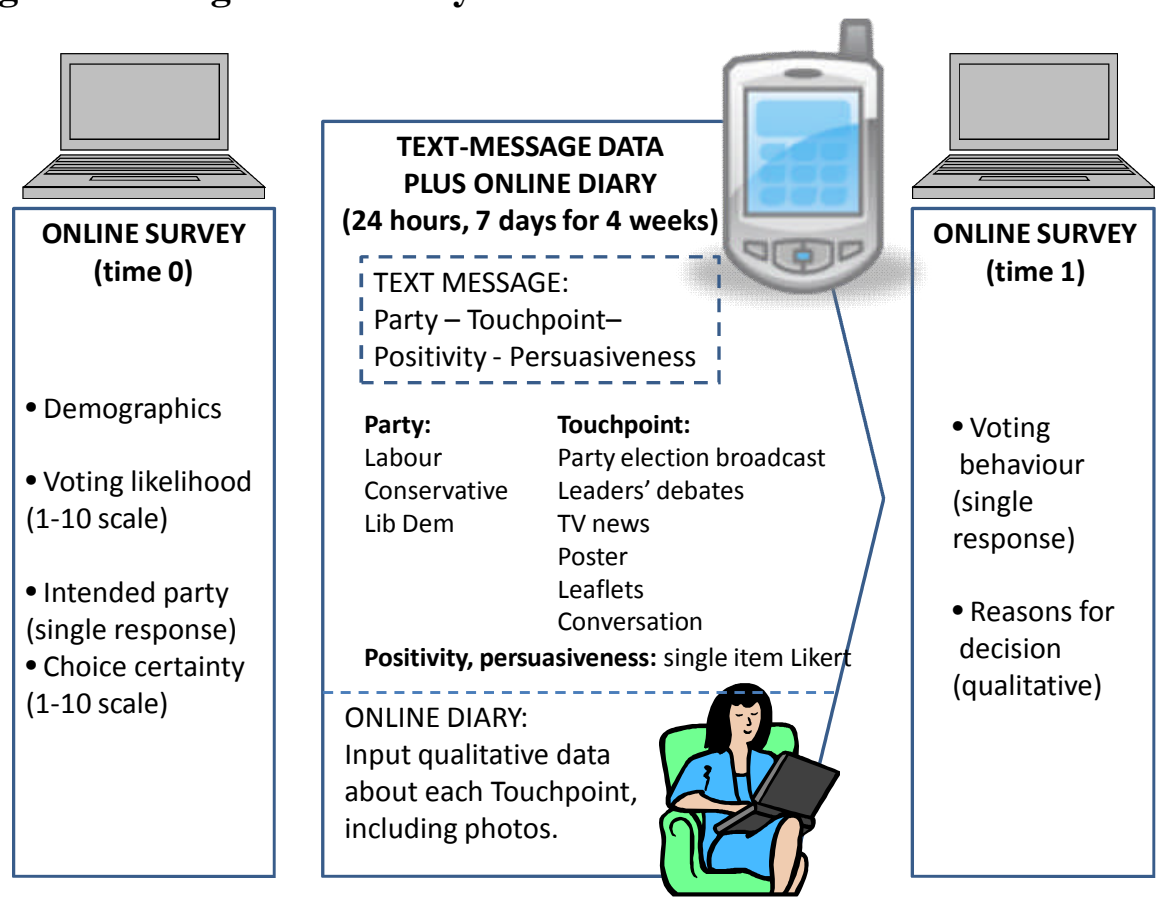

The design of the study

The study design integrates online and mobile phone technologies (as per Figure 1). At time t0, respondents completed an online survey which collected their demographic information. This online survey also measured their likelihood to vote in the upcoming general election (1-10 scale, anchored by $1=$ absolutely certain not to vote and $10=$ absolutely certain to vote), which party they would vote for (single response), and their certainty of voting for the selected party (1-10 scale, $1=$ not at all certain to $10=$ absolutely certain). At time $\mathrm{t} 1$, four weeks later and immediately following polling day, the same respondents again completed an online survey which measured reported voting behaviour including whether they voted (single response) and which party they 
voted for (single response). Qualitative data were also collected at time $\mathrm{t} 1$ with regards to the reason for the voting decision.

In between time $t 0$ and time $\mathrm{t} 1$, respondents provided mobile phone text messages each time they experienced a touchpoint related to the election campaign. Each text message provided information about:

1) the relevant party;

2) the touchpoint type;

3) positivity: the valence of the immediate emotional response to the communication (a single Likert-scale item, "How did it make you feel?", on a 5-point scale anchored by "very positive' and 'very negative'); and

4) persuasiveness: the immediate self-assessed impact on consideration (a single Likert-scale item, "How much more likely did it make you to vote for this party in the election?", on a 5point scale anchored by 'much more likely' and 'much less likely').

While a variety of touchpoint types were collected, we focus primarily on six categories on which response volumes allowed statistical analysis: Party election broadcasts; Leaders' Debates; TV News; Posters; Leaflets; and Conversations. In addition to the self-assessed persuasiveness measure, the impact of touchpoints on voting behaviour was assessed statistically (see next section).

Across the four weeks, our sample of respondents reported on 8,160 touchpoint experiences. The mobile phone responses were available for the respondents to review via their online diary which they were encouraged to update every two days. In the online diary, respondents could provide further detail about the nature of the touchpoint experience, including the provision of further qualitative response and uploading photos, providing on average 14.3 qualitative comments over the campaign period. 


\section{Findings and discussion}

\section{Descriptive analysis}

By aggregating the touchpoint persuasiveness ratings across touchpoint types, we can track the cognitive response of the panel of floating voters across the whole of the campaign using the realtime tracking approach. Figure 2 indicates positive and negative persuasiveness ratings of the three main British parties' messages during the 2010 election campaign for the floating voter panel. Dotted lines indicate negative persuasiveness (a particular experience made a respondent less likely to vote for the subject party); the full lines indicate positive persuasiveness (a particular experience made a respondent more likely to vote for the subject party). The graph indicates how the first and last TV debates in the 2010 British general election were particularly important in persuading floating voters to report an intention to vote for the Liberal Democrats and Conservatives respectively. In fact, come polling day itself, many of those intending to vote Liberal Democrat failed to translate their intentions into actual votes, particularly among younger voters (Whiteley, Sanders \& Stewart, 2010). Whilst our study does not provide a clear indication of why those who intended to vote Liberal Democrat did not eventually go on to vote for that party, we speculate that the reason why they did not is because their conviction to go out and vote Liberal Democrat was less strongly held than voters' conviction to vote for the other two main parties; in other words, the Liberal Democrat vote was more volatile (see also Worcester $\underline{e t ~ a l, ~ 2011) . ~ A ~ l i g h t l y ~ h e l d ~ i n t e n t i o n ~}$ might hence have been more subject to contrary influence from subsequent touchpoints, such as the negative effect on Liberal Democrat voting of both Conservative and Liberal Democrat posters which we discuss later. 


\section{Figure 2: Persuasiveness of party messaging}

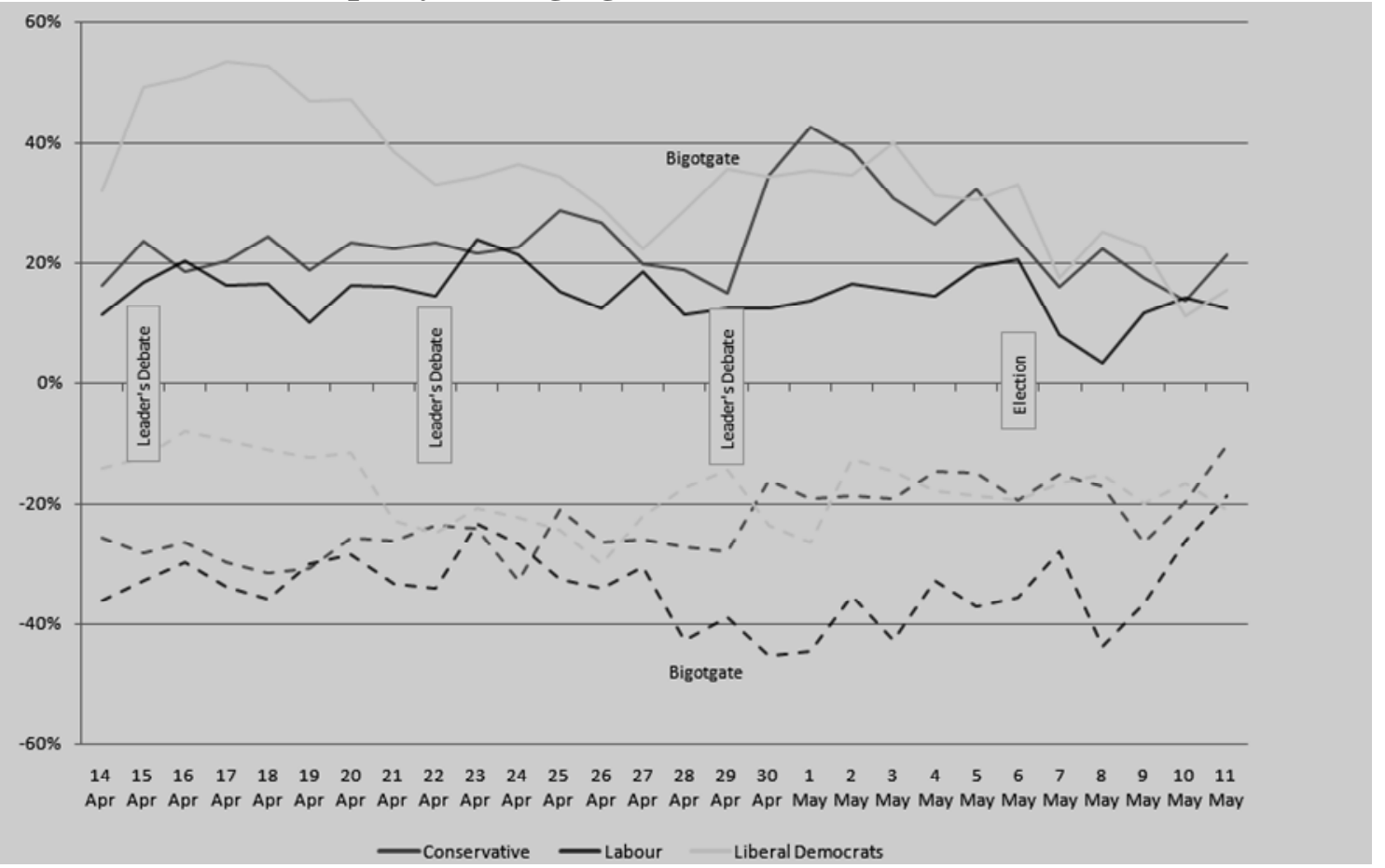

What the real-time tracking approach also clearly indicates amongst our floating voter panel is the impact on persuasiveness when Labour Prime Minister Gordon Brown declared a voter to be a 'bigoted woman' (because she raised her concerns about immigration issues) when caught on microphone in an unguarded moment. The media, in a pique of schadenfraude, called it 'bigotgate'. A sheepish looking Gordon Brown conceded in the final debate, 'there's a lot to this job and as you saw yesterday, I don't get all of it right'. His gaffe certainly made our panel of floating voters less inclined to vote Labour, as the following diary comment from a Labour leaning floating voter indicates:

'Calling the calm, well mannered, archetypal English voter, who dared to bring up the massive problem of immigration, a bigot, this was a blunder of the highest order by our Prime Minister. It showed him to be the untrustworthy, inconsiderate, dishonest and uncaring man that I knew him to be... it will be the final nail in the coffin of his disastrous leadership.'

Real-time tracking also indicated the rise in support for the Liberal Democrats, particularly after the 
first and, to a lesser extent, the second, debates, although this support began to taper off towards the end of the campaign. Table 2 illustrates that a great deal of switching occurred amongst the panel of floating voters over the period of the study. For instance, $31 \%$ of Labour voters had originally intended to vote Conservative, $23 \%$ of Conservative voters intended to vote Liberal Democrat and, by comparison, $22 \%$ of Liberal Democrat voters intended to vote Labour.

Table 2: Source of final voters

\begin{tabular}{|c|c|c|c|c|c|c|c|c|c|}
\hline \multirow{2}{*}{\multicolumn{2}{|c|}{ FinalVote }} & \multicolumn{8}{|c|}{ Initial intentions } \\
\hline & & \multicolumn{2}{|c|}{ Labour } & \multicolumn{2}{|c|}{ Conservative } & \multicolumn{2}{|c|}{ Lib Dem } & \multicolumn{2}{|c|}{ Don't know } \\
\hline & $\mathbf{n}$ & $\mathbf{n}$ & $\%$ & $\mathrm{n}$ & $\%$ & $\mathbf{n}$ & $\%$ & $\mathbf{n}$ & $\%$ \\
\hline Conservative & 139 & 20 & $14 \%$ & 35 & $25 \%$ & 32 & $23 \%$ & 35 & $25 \%$ \\
\hline Labour & 102 & 24 & $24 \%$ & 32 & $31 \%$ & 14 & $14 \%$ & 21 & $21 \%$ \\
\hline Lib Dem & 155 & 34 & $22 \%$ & 32 & $21 \%$ & 30 & $19 \%$ & 42 & $27 \%$ \\
\hline TOTAL & 396 & & & & & & & & \\
\hline
\end{tabular}

If we consider each party's touchpoints and the final vote that respondents made (see Table 3 ), the leaders' debates and the TV news are the touchpoints most frequently encountered. In both cases, these touchpoints are not direct channels to the voter and are mediated by third parties. The most influential touchpoint experience for those in our sample that eventually voted Conservative was the leaders' debate (in relation to both David Cameron and Nick Clegg), as we discuss in detail later (see Table 4). In contrast, the TV news, when Conservatives were the subject of the report, had a seemingly negative effect on Conservative floating voters' voting intentions, as it did for the other two main parties. This seemingly indicates that TV news has an overall negative persuasive effect. Party election broadcasts (PEBs) had a mixed reception amongst our sample; frequently they had an immediately positive affective impact but an immediately negative self-assessed effect on voting intention (for example all types of floating voters encountering a Conservative PEB). This result is difficult to explain, though could be an underdog effect (note that Labour floaters encountering a Labour PEB had the opposite effect, i.e. an initial negative affective response but more positive voting intention). Posters in all cases, excluding Labour posters seen by floating voters who ended up voting Labour, were negatively received. One of our diarists, commenting on the Conservative $\mathbf{1 8} \mid \mathrm{P}$ a g e 
poster displaying a smiling (insincere-looking) Brown with associated negative messages (for example, 'I doubled the national debt, vote for me'), described the posters as 'positively Orwellian'. Leaflets were positively received by both samples of Labour and Conservative floating voters when they received them from both parties. In contrast, the Liberal Democrat sample of floating voters were not particularly persuaded by any party's leaflets. Curiously, the data in Table 3 indicate that only the Labour party benefitted from positively persuasive word-of-mouth, on average, over the course of the campaign. Recall, however, that the data shown in Table 3 are based on self-reported impact on voting intentions at the time of the touchpoint. 
Table 3: Touchpoints encountered by floating voters for each party by final vote

\begin{tabular}{|c|c|c|c|c|c|c|c|c|c|c|c|c|c|}
\hline & & \multicolumn{4}{|c|}{ Voted Conservative } & \multicolumn{4}{|c|}{ Voted Labour } & \multicolumn{4}{|c|}{ Voted Lib Dem } \\
\hline & & $\mathbf{n}$ & $\%$ & Positivity & $\begin{array}{l}\text { Persuasive- } \\
\text { ness }\end{array}$ & $\mathbf{n}$ & $\%$ & Positivity & $\begin{array}{l}\text { Persuasive- } \\
\text { ness }\end{array}$ & $\mathbf{n}$ & $\%$ & Positivity & $\begin{array}{l}\text { Persuasive- } \\
\text { ness }\end{array}$ \\
\hline \multicolumn{14}{|c|}{ Touchpoint types encountered: } \\
\hline \multirow[t]{6}{*}{ Conservative } & Party election broadcast & 26 & $19 \%$ & 3.27 & 2.92 & 29 & $28 \%$ & 3.36 & 2.65 & 45 & $29 \%$ & 3.07 & 2.85 \\
\hline & Leaders' debate & 68 & $49 \%$ & 3.30 & 3.28 & 57 & $56 \%$ & 3.34 & 3.29 & 83 & $54 \%$ & 3.24 & 3.18 \\
\hline & Poster & 41 & $29 \%$ & 2.82 & 2.85 & 33 & $32 \%$ & 2.83 & 2.75 & 37 & $24 \%$ & 2.76 & 2.84 \\
\hline & Leaflet & 61 & $44 \%$ & 3.03 & 3.06 & 43 & $42 \%$ & 3.17 & 3.06 & 58 & $37 \%$ & 2.95 & 2.98 \\
\hline & TV News & 91 & $65 \%$ & 2.85 & 2.87 & 66 & $65 \%$ & 2.91 & 2.97 & 105 & $68 \%$ & 2.91 & 2.89 \\
\hline & Word-of-mouth & 30 & $22 \%$ & 2.80 & 2.69 & 24 & $24 \%$ & 3.00 & 2.65 & 39 & $25 \%$ & 2.93 & 2.77 \\
\hline \multirow[t]{6}{*}{ Labour } & Party election broadcast & 23 & $17 \%$ & 2.92 & 2.79 【 & 30 & $2 \overline{9} \%$ & $\overline{2.86}$ & $\overline{3.04}$ & 38 & $25 \%$ & 3.07 & 3.06 \\
\hline & Leaders' debate & 70 & $50 \%$ & 3.10 & 3.07 & 58 & $57 \%$ & 3.23 & 3.14 & 83 & $54 \%$ & 3.22 & 3.29 \\
\hline & Poster & 41 & $29 \%$ & 2.74 & 2.97 I & 26 & $25 \%$ & 3.16 & $3.05 !$ & 35 & $23 \%$ & 2.53 & 2.69 \\
\hline & Leaflet & 52 & $37 \%$ & 3.03 & 3.001 & 30 & $29 \%$ & 3.13 & 3.041 & 63 & $41 \%$ & 2.81 & 2.81 \\
\hline & TV News & 86 & $62 \%$ & 2.92 & $2.86 \mid$ & 69 & $68 \%$ & 2.93 & 2.961 & 90 & $58 \%$ & 2.77 & 2.82 \\
\hline & Word-of-mouth & 31 & $22 \%$ & 2.74 & $2.81 !$ & 29 & $28 \%$ & 3.21 & 3.081 & 46 & $30 \%$ & 2.82 & 2.79 \\
\hline \multirow[t]{6}{*}{ Lib Dem } & Party election broadcast & 28 & $20 \%$ & 2.88 & 2.92 & 31 & $30 \%$ & 2.94 & $2.83 !$ & $\overline{39}$ & $\overline{25} \overline{0}$ & 3.06 & 2.97 \\
\hline & Leaders' debate & 46 & $33 \%$ & 3.30 & 3.21 & 45 & $44 \%$ & 3.06 & 3.06 & 66 & $43 \%$ & 3.26 & 3.35 \\
\hline & Poster & 49 & $35 \%$ & 2.85 & 2.82 & 31 & $30 \%$ & 2.98 & $2.71 !$ & 50 & $32 \%$ & 2.82 & $2.84 !$ \\
\hline & Leaflet & 55 & $40 \%$ & 3.00 & 2.91 & 44 & $43 \%$ & 2.82 & $2.70 !$ & 64 & $41 \%$ & 2.84 & 2.86 l \\
\hline & TV News & 84 & $60 \%$ & 2.77 & 2.82 & 72 & $71 \%$ & 2.81 & $2.98 !$ & 100 & $65 \%$ & 2.85 & 2.85 \\
\hline & Word-of-mouth & 38 & $27 \%$ & 2.80 & 2.97 & 19 & $19 \%$ & 2.68 & 2.88 & 43 & $28 \%$ & 2.69 & ا \\
\hline \multicolumn{2}{|c|}{ TOTAL SAMPLE OF VOTERS } & 139 & & & & 102 & & & & 155 & & & \\
\hline
\end{tabular}

Note: Positivity and persuasiveness measured in real time using single-item Likert measure in text message. Where the respondent reported more than 1 instance of

the touchpoint type for a particular party, the average score across such touchpoints is shown. 


\section{The impact of touchpoints on voting behaviour}

To explore the impact of touchpoints on voting behaviour, we examine associations between touchpoint occurrence and the subsequent vote. We allow for competitor effects, so a touchpoint for party A may impact on voting for party B. Significant associations for 13 touchpoint experiences (TP1 - TP13) are shown in Table 4 and discussed in the following sections. Bivariate analysis using a chi-squared test is used as the data contains numerous missing values and differential numbers of entries per respondent, rendering multivariate approaches such as regression or structural equation modelling impractical without a serious loss of statistical power. Specifically, as respondents have strong prior relationships with party brands, the analysis examines the impact of touchpoint occurrence on whether or not the respondent shifts from their initial intended party and, if so, to which alternative party. Hence, for each analysis, the $n$ value is determined by the number of respondents who initially intended to vote for a certain party, while the analysis examines whether exposure to a touchpoint was significantly associated with how this group actually voted. Table 4 shows several significant, and in some cases perhaps counter-intuitive, associative relationships at the $\mathrm{p}<0.05$ level (we omit insignificant associations for simplicity). Some of these results show a simple association between intentions and final behaviour, mediated by the same party. Others indicate a trade-off between two parties, while others seem to indicate an interaction between all three parties. Interestingly, no significant associations were identified for TV News. We consider each of the significant touchpoint experiences (TP1-TP13) next.

\section{TP1-TP3: Labour party election broadcasts}

Amongst the group of 114 respondents who initially intended to vote Conservative, being exposed to a Labour party election broadcast was significantly associated with switching to Labour. A smaller proportion of Liberal Democrats who saw the Labour PEB continued to vote for Liberal Democrat and an equal proportion to this group switched to the Conservatives. 
Table 4: Significant touchpoint experiences (TP1-TP13)

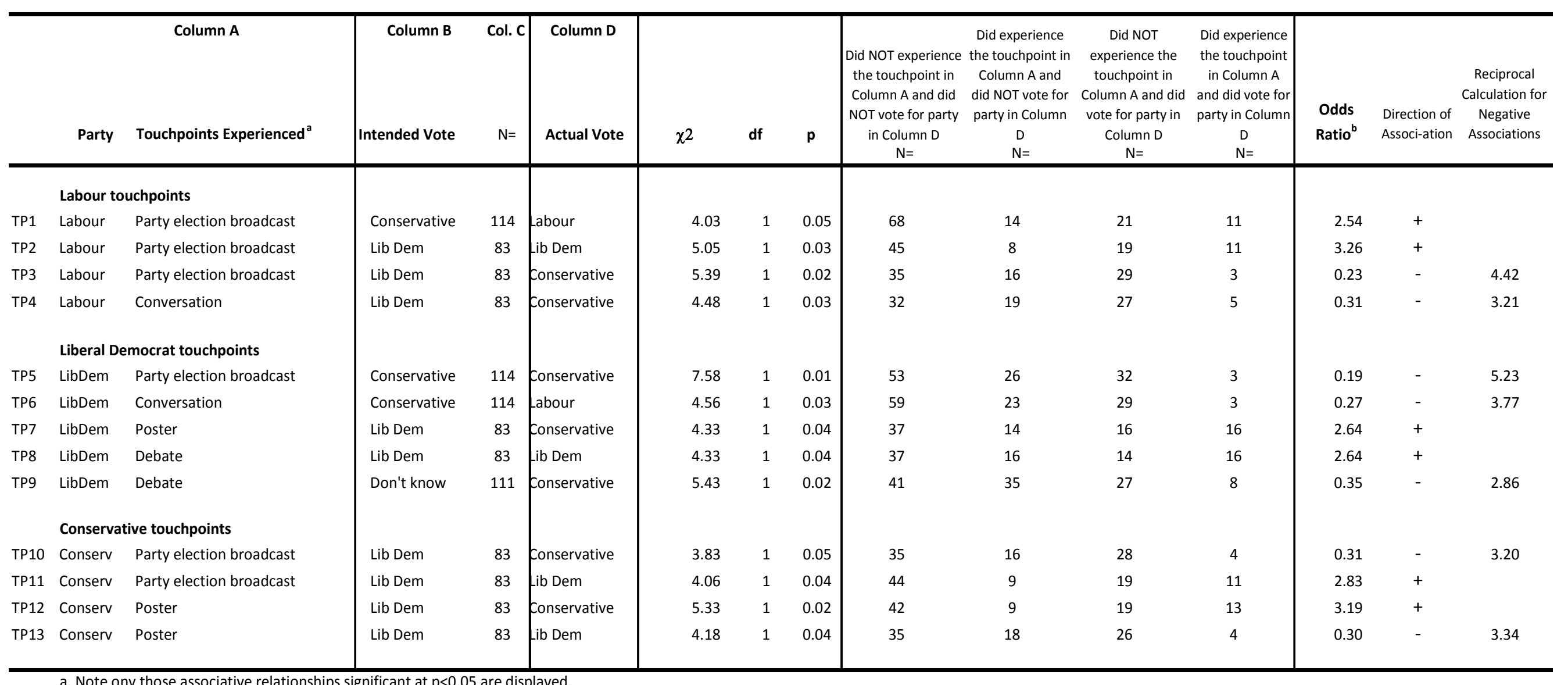

a. Note ony those associative relationships significant at $p<0.05$ are displayed. 


\section{Those who intended to vote Liberal Democrat and reported a conversation about Labour were}

three times less likely to vote Conservative. Although much of the conversation amongst Liberal Democrat intenders in the sample who did not vote Conservative was negative about Labour and Gordon Brown, Table 3 indicates that on average it was more positive than negative. Specific comments related to their perceptions of a tired Labour government and issues over Iraq. There was one explicit reference to not wanting the Conservatives to get into power: 'Talking to friends at a house party about the election - one of the friends was a teacher and she was telling me about her misgivings about a Tory government.' While it is difficult to interpret this complex result confidently, it may be that despite negative comments about Labour, the act of our sample of Liberal Democrat intenders discussing Labour emphasized Labour and the Liberal Democrats as the primary choice set.

\section{TP5: Liberal Democrat party election broadcasts}

Those who intended to vote Conservative and saw a Liberal Democrat PEB were five times more likely to defect from the Conservatives ${ }^{2}$. Qualitative comments suggest that most people who defected from the Conservatives in our sample were impressed by the Liberal Democrat broadcast. Nick Clegg was perceived as coming across well and speaking common sense. In particular, his education policies were praised. His change message particularly resonated as illustrated in the following comment:

'[A] party political broadcast going through what the Lib Dems hope to do should they win the election and the main message is we have been putting up with bad management of the UK from to-ing and fro-ing of Labour and Conservative governments for [the] past 60 odd years. It's time to give the Lib Dems a chance'.

\footnotetext{
${ }^{2}$ This is calculated as the reciprocal of the odds ratio for those who intended to vote Conservative and then experienced the LibDem PEB. The odds ratio of 0.19 indicates a negative association; the reciprocal calcuted as $1 /$ (odds ratio) $=$ 5.23 provides the strength of the association in the alternative direction.
} 
TP6: Conversation about the Liberal Democrats

Those who intended to vote Conservative and had a conversation about the Liberal Democrats were more than three times less likely to vote Labour. In our sample, those intending to vote Conservative who voted either Conservative or Liberal Democrat had positive conversations about the Liberal Democrats. They covered Nick Clegg's widely reported 'win' of the first leaders' debate and his credibility. However, this finding seemingly contradicts the data outlined in Table 3, where Liberal Democrat word-of-mouth has a seemingly slightly negative effect on a self-assessed basis. As with our discussion of TP1, this finding emphasizes that self-assessed persuasiveness does not necessarily equate to longer-term observed persuasiveness.

\section{TP7: Liberal Democrat posters}

Those who intended to vote Liberal Democrat and saw a Liberal Democrat poster were twice more likely to switch to Conservatives. Amongst this floating voter sample, posters generally were among the least persuasive and positively received touchpoints, along with word-of-mouth; and even Liberal Democrat-leaning floating voters were no more positive about Liberal Democrat posters than they were about Conservative ones (Table 3). Nonetheless, despite this lack of selfassessed positivity, statistically they seemed to have played a role (see also TP12 and TP13). Comments in the online diaries confirm that the majority of Liberal Democrat posters were local, in support of individual MPs. Those expressing positive views were mostly impressed by the evidence of winnability that the display of posters by their neighbours suggested:

'A few shops down there was another poster ... it made me feel positive that there is so much support for the Lib Dems and more likely to vote because they have a good chance of getting more seats and thus more influence at this election.' 
If winnability is a genuine consideration, however, it is also one subject to rapid change. As momentum shifted from the Liberal Democrats to the Conservatives in media coverage and hence in touchpoint experience as a whole in the later weeks (Figure 2), some Liberal Democrat intenders may have concluded that the Conservatives were the likelier to win of their primary choice set of Liberal Democrat and Conservative (Table 2).

If this offers a possible explanation for the lack of a positive impact of Liberal Democrat poster encounters, the reasons for the observed negative impact are not clear. One possible explanation is in the perceived amateurism of the Liberal Democrat posters: '[I saw a] big orange poster on a side of a house. [I] have seen quite a few similar [ones] around Liverpool. It said the tide is turning, vote Lib Dem. [But it] didn't look professional...'.

If, as has frequently been speculated, voters are more risk-averse when casting their actual vote than when discussing their intentions earlier in the campaign, a perceived amateurism might have been a sufficiently poor brand association to account for this negative effect. Consumers tend to attribute a personality to the brand holistically (Aaker, Fournier \& Brasal, 2004), and so an amateurism in poster production might plausibly suggest an amateurism in office. This interpretation is consistent with the findings of Macdonald and Wilson (2010), who found that scruffy, poorly run charity shops lead customers to conclude that the charity as a whole is poorly run and may not be effective in its field operations. Further exploration might usefully include measuring professionalism as a brand attitude both before and after the campaign, and examining whether poster or other touchpoints are associated with shifts in this attitude.

TP8 and TP9: Liberal Democrat leaders' debates

Those who intended to vote Liberal Democrat and commented on the Liberal Democrats in the debate were twice as likely to vote Liberal Democrats. It was clear that Nick Clegg came across 
well to our sample of Liberal Democrat intenders. It was his honesty, 'newness' and confidence that struck a chord with people, but so did his perceived grasp of policy. He seemed to be a credible leader with the right ideas for the country, as the following comments demonstrate:

'Nick Clegg came across as being honest and reliable. Almost like breath of fresh air. He seemed confident, with original ideas especially on education.'

'I thought Nick looked authoritative, confident and much more Prime Ministerial than his opponent'

'I thought Nick Clegg was articulate and seemed to have a much better plan for getting this country out of the current economic situation.'

There was naturally an intensive media discussion about the leaders' debates and how each leader came across. It is notable that only SMS texts relating to the Liberal Democrat leader were significantly associated with the outcome. This is consistent with the media's contemporaneous interpretation of the first debate that the less well-known candidate Nick Clegg had the most to gain, and that through mastering the debate medium faster than his opponents, he took this opportunity. The statistical analysis suggests that although this advantage was diluted later in the campaign, it nevertheless seemed to protect the intending Liberal Democrat vote, as well as encouraging 'don't knows' to vote Liberal Democrat, as we turn to next.

Those who didn't know who to vote for and texted about the Liberal Democrats in a debate were less likely to vote Conservative. While the group in our sample of initial don't knows (those expressing no initial preference, however tentative, in the survey at time 0) who did not vote Conservative are slightly less effusive in their response to Nick Clegg in comments on the leaders' debates than intending Liberal Democrats, the majority of comments are nevertheless positive, 
suggesting that this touchpoint was swaying people towards Liberal Democrat and away from the Conservatives. For example:

'It was such a surprise to see Nick Clegg come over so well during the debate. He was relaxed, articulate and empathised with the audience very well. He certainly came out on top of the three leaders - a very impressive performance'.

'Nick Clegg interacted well with the audience and the cameras.'

We commented earlier that Conservatives and Liberal Democrats appeared to have formed the primary choice set for intending Liberal Democrats; that this finding specifically concerned the Conservatives may suggest that the same is the case for initial don't knows.

TP10 and TP11: Conservative party election broadcasts

Those who intended to vote Liberal Democrat and saw a Conservative PEB were almost three times more likely to vote Liberal Democrat and three times less likely to vote Conservative. Like leaflets and posters, party election broadcasts (PEBs) are effectively brand-controlled touchpoints which one would expect to be positively associated with voting for the party. The Conservative broadcasts, however, in common with the Liberal posters, backfired with one important group within the sample: intending Liberal Democrat voters. Although many of this group switched to Conservative as the Conservatives gained momentum in the election, those who saw a Conservative PEB were far less likely to do so. In the reaction to this polarizing touchpoint, amongst our sample those who found the PEB off-putting disliked Cameron's negative campaigning against a hung parliament and negative campaigning more generally as the following diary comments indicate: 
'David Cameron was banging on about how wonderful everything is going to be if he is elected and how awful and uncertain things will be if either of the other two [parties] are elected.'

'This broadcast did not tell us what the Conservatives would do to help the country. [It] just spoke badly of the other parties saying how terrible it would be to have a hung parliament.'

Those in our sample who intended to vote Liberal Democrat and either voted for them or Labour were critical of the Conservative PEB (corroborating evidence also in Table 4). These floating voters either disliked David Cameron or did not trust the Conservatives. Diarists had the following comments:

'I watched David Cameron's election broadcast in his garden. He was elaborating on his 'big society' idea. I like the concept but can't really bring myself to trust the Conservative Party although I like David Cameron. I keep thinking about the Thatcher years and high unemployment and the miner's strike and I would hate to see those times back again. My fears about the Conservatives will almost certainly mean I will still vote Lib Dem.'

'I can't take this man [David Cameron] seriously with regard to [him] being a 'man of the people'.'

TP12 and TP13: Conservative posters

When Lib Dem intenders experienced a Conservative poster, then they were three times more likely to vote Conservative and three times less likely to vote Lib Dem. Conservative posters provide another interesting example of a touchpoint which may have had more influence on our sample panel of floating voters' behaviour than they realized. This is perhaps not surprising as the impact of above-the-line media is often underestimated by consumers (Cowley, 2002). In our analysis the impact of the Conservatives' posters shows up in both encouraging Conservative votes 
and reducing the likelihood of Liberal Democrat ones. This positive impact of Conservative posters on actual vote cast is in contrast to the voters' perceptions of touchpoint influence, as expressed by their real-time persuasion score. In general the immediate reaction to Posters as reported in the SMS text tends to make no difference to voting intentions. Of the 1273 Poster touchpoints the sample texted about, $69 \%$ were thought to have made no difference, with $4 \%$ much more likely to vote for the party as a result, $11 \%$ slightly more likely, $7 \%$ slightly less likely and 9\% much less likely.

Within our sample, the qualitative response to Conservative posters from Liberal Democrat intended voters who subsequently switched is mixed. There was the response to the Conservative Party's negative campaigning featuring a smiling Gordon Brown, which was disliked and potentially could have swayed people to vote for Labour, as the following comment demonstrates:

'It was a picture of Gordon Brown with something like "I let 84,000 prisoners out of jail early, let me do it again”. I really didn't like the negative slant and that, in fact, it didn't even attack policy but focused on events. I had been starting to consider voting Conservative from some of the positive policy messages I had been hearing but this negative, badmouthing campaign has put me off - I want to hear what they are going to do for me, not them slagging off the opposition. I also think it undermimes the fact that most voters can make up their own mind, we do not need to hear what you think of the other party.'

On the other hand, there were some positive messages coming through later in the campaign which may have been persuading people to vote Conservative, as the following diarist outlines: ' [ I saw a] poster telling people that the Conservatives will introduce citizen service for 16 year olds. Though it isn't quite clear from the poster what that is, from the implication it sounded like a positive thing to me.' And there were also local Conservative posters. These may have been giving people the 
confidence to vote Conservative by suggesting that the party had local backing - i.e. social proof and was likely to win, as the following comment indicates:

'I walked into town this afternoon and saw two new Conservative garden posters but still no Labour ones at all. There are Lib Dem and Conservative posters in roughly equal numbers in our small rural town... Labour have certainly been conspicuous by their absence and that has not been the case in previous elections here when they have contested this constituency vigorously.'

In general, however, qualitative comments about Conservative posters were negative, which might have been expected to push some who were Liberal Democrat intenders to vote Labour in a tactical manner to reduce the Conservative's chance of winning in a particular seat. Some people disliked either the negative campaigning or the policies. Others felt that the location of Conservative posters outside big houses was a reminder that they were in favour of rich over poor. However, there were a minority of positive comments about Conservative posters which may have swayed some Liberal Democrat intenders to vote Conservative. For example:

'[This poster] did not feature any politician, but it was a well dressed, smiling middle aged woman with the caption 'I've never voted Tory before but they're serious about sorting out MP's expenses". I was driving through Dundee when i seen [sic] this.'

Overall, it could simply be that while consciously disliked by some when they paid the poster cognitive attention in the act of texting, the negative anti-Brown posters nevertheless had the desired effect. 


\section{Limitations and further research}

In this pilot of the use of real-time experience tracking for a political campaign, some limitations should be noted. Firstly, because the study was undertaken over a four-week campaign period, a high drop-out rate was obtained (a common problem in panel studies - see McGivern, 2003: 79-82), since some respondents lost enthusiasm and left the study before the election itself. It is possible that those respondents that dropped out were significantly different in some way from those that were retained. Secondly, respondents self-reported their actual vote, which may have been prone to some recall error. Thirdly, respondents are expected to send messages whenever they experience a particular touchpoint. It is possible that as they become au fait with the technology and the method that they succumb to panel effects such as fatigue (not undertaking the task as assigned) or conditioning (where the behaviour of the panel becomes affected by the research approach). Fourthly, our survey did not differentiate between billboard posters and election posters placed in peoples' gardens or windows, although panel respondents did differentiate between these in their online diaries. Finally, our study reported only on the six most experienced touchpoints even though other touchpoints may also have influenced how the sample voted (e.g. internet spoof adverts, MPs' websites, press news, etc.). Further research should therefore be undertaken into the use of realtime tracking approaches to investigate the above potential concerns further. Future research studies would ideally make use of nationally representative samples, controlling for drop-out by weighting the final sample accordingly before analysis. Such an approach would ensure that campaign influence effects could be definitively determined across voter groups.

This study outlines the feasibility and importance of undertaking marketing research to evaluate channel effectiveness in the marketing of a political party. As outlined in the introduction, few parties actually conduct any sophisticated post-election research (Baines, 2005). The methodology outlined here to track channel effectiveness is relatively cost-effective, and is easy and quick to obtain. Yet, clearly, unanswered questions arise as to the validity and generalisability of these data. 
Can such data be representative of the general population, for example? All online panel samples are subject to the critique that the self-selection may result in biases which only truly random sampling can ameliorate. Secondly, are data obtained on a frequent and regular basis by mobile phone based on channel experiences more or less valid than those obtained in a typical opinion poll survey? While it seems plausible that real-time tracking will be more accurate than subsequent recollection, the act of asking respondents to text - however briefly - is inevitably a threat to ecological validity. We would hence presume that comparisons between brands are more to be trusted than the absolute numbers of touchpoints reported within a brand. A third question arises as to whether or not this method is useful in different cultural contexts, where mobile phone use may differ, depending on age, status, socio-economic group, type of media systems in operation and media literacy, and education levels. Each of these issues requires further investigation.

Within these limitations, this research forms a pilot of a new method for analysing the relative efficacy of differential channel use for marketing purposes, applying the method to the United Kingdom 2010 general election amongst a panel of floating voters. The question arises as to whether or not the efficacy of these channels will change in different elections and contexts, and if so, how and why? For example, communication channel effectiveness may vary by country. There is some evidence that combination effects exist when voters receive the same congruent messages from different sources (Carey \& Burton, 2004). Further research into how these work, in what combinations, and with what effects, might be suited to the real-time tracking approach we have described or a variant on it.

\section{Conclusions}

The main contribution of this article is to illustrate a method by which political parties (and other brands) can track customer responses to customer experience holistically and in real time, and to 
pilot its use to evaluate the impact of multichannel communications. Parties and brand-owners may wish to experiment with such customer insight techniques in order to refine their multichannel communications and build a dynamic capability which competitors might find difficult to copy (Wilson \& Daniel, 2007). This would certainly be a significant step in the political context, in which parties rarely evaluate the voters' channel preferences or their own communication effectiveness (Baines, 2005), except perhaps to determine their voters' self-assessed channel preferences gleaned from private polling.

A secondary, more tentative contribution is to illustrate how floating voters experienced different political party touchpoints during the 2010 general election. We identify 13 significant associative relationships between the way that floating voters voted and their interaction with specific party touchpoints. In particular, we chart the influence of the election campaign debates - particularly the first one in raising the profile of the Liberal Democrat leader Nick Clegg, although the party's voteshare only increased by $1 \%$ and its seats by five in the final result. The debates did, however, make Clegg (and his party) sufficiently popular to make them palatable coalition partners when it became clear that the final election result was a hung parliament. As a touchpoint, the debate had particular significance for those in our sample who ended up voting Liberal Democrat, either where they intended to vote Liberal Democrat or where they initially did not know who to vote for. In previous elections, the debate had not included all three main parties simultaneously, or had not been set up with live studio audiences, or as a combative debate, or across a comprehensive set of political issues. In 2010, the format of the three debates with all three main party leaders present and a skilled questioner in front of a studio audience meant much larger audiences viewed these debates than their previous debate incarnations, with the first debate peaking at $10.3 \mathrm{~m}$ viewers, becoming the fourth most watched show of the year (Anon., 2010). The implication for political parties and their leaders is that they need to be prepared, have tested their policies and statements, be trained and have rehearsed (to ensure appropriate tone and argumentation). This places a stronger emphasis 
on campaign rhetoric and dialogue than in the past - something that has been more common in America than in UK campaigns historically.

However, we also note the apparent relationships between viewing a PEB and voting intention for floating voters. The findings seem to indicate a serious weakness in the Conservative Party media strategy: their PEBs were off-putting and drove floating voters into the arms of the opposition. The Conservatives seem to have been most successful with their poster campaign, as far as the floating voter panel was concerned. Our analysis did not uncover any significant touchpoint associative relationships where the floating voter panel members intended to vote Labour at the $p<0.05$ level. Gordon Brown's 'Bigotgate' gaffe may have entertained the media but there was no indication in our data that it changed the direction in which the campaign was already heading.

The method outlined in this study provides an innovative approach to measuring party success, investigating channel effectiveness for marketing purposes, and in particular shedding light on the influence of the TV debates as well as highlighting the role of the somewhat less high-profile party election broadcasts and posters. We hope thereby to open out the discussion of, and experimentation with, real-time tracking approaches for longitudinal communication research, not just in the political sphere but for other brands where multiple communication experiences must also be disentangled. 


\section{Appendix A: Sample Profile}

$\begin{array}{ll}\text { Gender } & \text { Sample \% } \\ \text { Male } & 46.7 \\ \text { Female } & 53.3 \\ \text { Age category } & \\ 18-24 & 12.7 \\ 25-34 & 15.6 \\ 35-44 & 22.3 \\ 45-54 & 18.3 \\ \text { Over 55 } & 31.0 \\ \text { Social status (JICNARS grading) } & \\ \text { A } & 9.4 \\ \text { B } & 24.8 \\ \text { C1 } & 23.5 \\ \text { C2 } & 15.2 \\ \text { D } & 9.6 \\ \text { E } & 17.5 \\ \text { Likelihood of voting } & \\ 1 \text { ('Absolutely certain not to vote') } & 0.6 \\ 2 & 0.8 \\ 3 & 1.5 \\ 4 & 2.1 \\ 5 & 1.9 \\ 6 & 2.9 \\ 7 & 6.5 \\ 8 & 10.8 \\ 9 & 16.3 \\ 10 \text { ('Absolutely certain to vote') } & 56.7\end{array}$

Sample Base: 480 GB floating voters aged 18+.

\section{References}

Aaker, J., Fournier, S., \& Brasal, S.A. (2004). When good brands do bad. Journal of Consumer Research, 31(1), 1-16.

Anon. (2010, 16 April). UK TV ratings: historic election debate attracts huge audience. TVbythe numbers, Retrieved from http://tvbythenumbers.com/2010/04/16/uk-tv-ratings-historic-electiondebate-attracts-huge-audience/48779.

Baines, P. (2005). Marketing the political message: American influences on British practices. Journal of Political Marketing, 4, 2/3, 135-162.

BBC (2001, nd). Challenge the leaders: Question Time election specials. BBC News, Retrieved from http://news.co.uk/news/vote2001/hi/english/question_time/ 
BBC (2005a, 29 April). Four million watch leader debate. BBC News, Retrieved from http://news.bbc.co.uk/1/hi/uk_politics/vote_2005/frontpage/4497707.stm

BBC (2005b, 28 April). Question time for party leaders. BBC News, Retrieved from http://news.bbc.co.uk

Carey, S. \& Burton, J. (2004). Research note: the influence of the press in shaping public opinion towards the European Union in Britain. Political Studies, 52, 3, 623-640.

COI/GCN (2009), Payback and return on marketing in the public sector: How to evaluate the financial effectiveness and efficiency of government marketing communications, London: Central Office of Information/Government Communications Network.

Courtheoux, R.J. (2003). Modeling multichannel response behaviour, Interactive Marketing, 5, 1, 1-15.

Cowley, E. (2002). East-West consumer confidence and accuracy in memory for product information. Journal of Business Research, 55, 11, 915-921.

Cowley, E. (2008). Looking back at an experience through rose-colored glasses. Journal of Business Research, 61, 1046-1052.

de Mattos, C.A. \& Rossi, C.A.V. (2008). Word-of-mouth communication in marketing: A metaanalytic review of the antecedents and moderators. Journal of the Academy of Marketing Science, 36, 578-596.

De Vreese, C.H. \& Semetko, H.A. (2004). Political campaigning in referendums: Framing the referendum issue, Abingdon, Oxon: Routledge.

Dermody, J. \& Scullion, R. (2003). Exploring the consequences of negative political advertising for liberal democracy. Journal of Political Marketing, 2, 1, 77-100.

Dermody, J. \& Hanmer-Lloyd, S. (2005). Promoting distrust? A chronicle of the 2005 British general election advertising campaigns. Journal of Marketing Management, 21, 1021-1047.

East, R.; Hammond, K. \& Lomax, W. (2008). Measuring the impact of positive and negative word-ofmouth on brand purchase probability. International Journal of Research in Marketing, 25, 3, 215-224. 
Field, A. (2005). Discovering statistics using SPSS, $2^{\text {nd }}$ Edition, London: Sage Publications.

Hansard Society (2001). Televised leaders' debates revisited: UK 2001 - A debate odyssey. Hansard Society, Retrieved from: http://www.hansardsociety.org.uk/files/folders/2130/download.aspx

Harris, P.; Lock, A. \& O’Shaughnessy, N. (1999). Measuring the effect of political advertising and the case of the 1995 Irish divorce referendum. Marketing Intelligence and Planning, 17, 6, 272-280.

Hames, T. \& Passmore, V. (2005), The Times Guide to the House of Commons 2005, London: Times Books Harper Collins Publishers.

Himmelweit, H.; Jaegar, M.; Stockdale B. \& Stockdale, J. (1978). Memory for past vote. British Journal Political Science, 8, 365-84.

Kaid, L.L. (2002). Political advertising and information seeking: Comparing exposure via traditional and internet channels. Journal of Advertising, XXXI, 1, 27-34.

Kaid, L.L. \& Johnston, A. (1991). Negative versus positive advertising in US presidential campaigns, 1960-1988. Journal of Communication, 41, 3, 53-64.

Keltner, D.; Kring, A.M. \& Bonnano, G.A. (1999). Fleeting signs of the course of life: Facial expression and personal adjustment. Current Directions in Psychological Science, 8, 1, 18-22.

Klein, J.G. \& Ahluwalia, R. (2005). Negativity in the evaluation of political candidates. Journal of Marketing, 69 (January), 131-142.

Lemke, F.; Clark, M. \& Wilson, H. (2011). Customer experience quality: An exploration in business and consumer contexts using repertory grid technique. Journal of the Academy of Marketing Science, Advance online publication. Doi.10.1007/S/11747-010-0219-0.

Lichtenstein, S.; Bednall, D.H.B. \& Adam, S. (2008). Marketing research and customer analytics: Interfunctional knowledge integration. International Journal of Technology Marketing, 3, 1, 8196.

Macdonald, E.K. \& Wilson, H. (2010, September). The real-time evolution of brand engagement with charities. Paper presented at the International Colloquium on Relationship Marketing (ICRM), Henley. 
McGivern, Y. (2003). The practice of market and social research. Harlow: FT Prentice-Hall.

Merrilees, B. \& Fenech, T. (2007). From catalog to web: B2B multi-channel marketing strategy. Industrial Marketing Management, 36, 1, 44-49.

Merritt, S. (1984). Negative political advertising: Some empirical findings. Journal of Advertising, 13, $3,27-38$.

Mehta, A. \& Purvis, S.C. (2003). Consumer response to print prescription drug advertising. Journal of Advertising Research, 43, 2, 194-206.

Milne, G.R. \& Gordon, M.E. (1994). A segmentation study of consumers' attitudes towards direct mail. Journal of Direct Marketing, 8, 2, 45-52.

Mortimore, R. (2010, May). That election in figures. Paper Presented to the Coventry Conversation, Coventry.

Moschis, G.P. \& Moore, R.L. (1982). A longitudinal study of television advertising effects. Journal of Consumer Research, 9, 3, 279-286.

Naik, P.A. \& Peters, K. (2009). A hierarchical marketing communications model of online and offline media synergies. Journal of Interactive Marketing, 23, 288-299.

Nicolson, M.; Clarke, I. \& Blakemore, M. (2002). 'One brand, three ways to shop': Situational variables and multichannel consumer behaviour. International Review of Retail, Distribution and Consumer Research, 12, 2, 131-148.

Norris, P.; Curtice, J. ; Sanders, D. ; Scammell, M. and Semtko, H.A. (1999), On message: Communicating the campaign. London: Sage Publications.

O’Cass, A. (2002). Political advertising believability and information source value during elections. Journal of Advertising, XXXI, 1, 63-74.

O'Cass, A. \& Pecotich, A, (2005). The dynamics of voter behaviour and influence processes in electoral markets: a consumer behaviour perspective. Journal of Business Research, 58, 406413. 
Parasurman, A. (1991). Marketing Research. Wokingham: Addison-Wesley Publishing Company.

Park, C.W. \& Young, S.M. (1986). Consumer response to television commercials: The impact of involvement and background music on brand attitude formation. Journal of Marketing Research, 23, 1, 11-24.

Perloff, R.M. (1999). The third person effect: A critical review and synthesis. Media Psychology, 1, 4, 353-378.

Pfeiffer, M. \& Zinnbauer, M. (2010). Can old media enhance new media? How traditional advertising pays off for an online social network. Journal of Advertising Research, 50, 1, 42-49.

Rettie, R.; Grandcolas, U. \& Deakins, B. (2005). Text message advertising: response rates and branding effects. Journal of Targeting, Measurement and Analysis for Marketing, 13, 4, 304-12.

Romer, D.; Kenski, K.; Waldman, P.; Adasiewicz, C.; \& Jamieson, K.H. (2004), Capturing campaign dynamics: The national Annenberg election survey, Oxford: Oxford University Press.

Rust, R.T.; Ambler, T. ; Carpenter, G.S. ; Kumar, V. \& Srivastava, R.K. (2004). Measuring marketing productivity: Current knowledge and future directions. Journal of Marketing, 68 (October), 7689.

Ryals, L. \& Wilson, H. (2005). Experimental methods in market research: from information to insight. International Journal of Market Research, 47, 4, 347-366

Sanderson, P. (1989). The odds ratio: A useful tool in neurosciences. Journal of Neurology, Neurosurgery and Psychiatry, 52, 817-820.

Scammell, M. \& Langer, A.I. (2006). Political advertising: Why is it so boring?. Media, Culture and Society, 28, 5, 763-784.

Schultz, D. \& Kitchen, P. (1997). Integrated marketing communications in US advertising agencies: An exploratory study. Journal of Advertising Research, September/October, 7-18.

Scullion, R. \& Dermody, J. (2005). The value of party election broadcasts for electoral engagement: A content analysis of the 2001 British general election. International Journal of Advertising, 24, 3, 345-372. 
Simon, J.L. \& Arndt, J. (1980). The shape of the advertising response function. Journal of Advertising Research, 20, 4, 676-784

Skowronski, J.J. \& Carlston, D.E. (1989). Negativity and extremity biases in impression formation: A review of explanations. Psychological Bulletin, 105, 889-906.

Sparrow, A. (2010, 2 March). Broadcasters reveal details of leaders' election debates. The Guardian, Retrieved from: http://www.guardian.co.uk/politics/2010/mar/02/details-leaderselection/debates

Taylor, C.R.; Franke, G.R. \& Bang, H-K. (2006). Use and effectiveness of billboards: Perspectives from selective-perception theory and retail-gravity models. Journal of Advertising, 35, 4, 21-43.

Verhoef, P.C. (2003). Understanding the effect of customer relationship management efforts on customer retention and customer share development", Journal of Marketing, 67, 30-45.

Verhoef, P.; Lemon, K.N.; Parasuraman, A.; Roggeveen, A.; Tsiros, M.; \& Schlesinger, L.A. (2009). Customer experience creation: Determinants, dynamics and management strategies. Journal of Retailing, 85, 31-41.

Whiteley, P.; Sanders, D. \& Stewart, M. (2010). Polling and forecasting the general election of 2010. International Journal of Market Research, 52, 5, 687-691.

Wilson, H. \& Daniel, E. (2007). The multi-channel challenge: A dynamic capability approach. Industrial Marketing Management, 36, 1, 10-20.

Worcester, R.M.; Mortimore, R. \& Baines, P. (2005). Explaining Labour's landslip, London: Politicos Publishing.

Worcester, R.M.; Mortimore, R.; Baines, P. and Gill, M. (2011). Cameron's coalition: Explaining the outcome of the 2010 British general election, London: Biteback Publishing. 